\title{
Assessment of Depression Status of Older Adults of Hisar City
}

\author{
Rupal Hooda ${ }^{1}$, Tanvi Bansal ${ }^{2}$ and Kiran Singh ${ }^{1}$ \\ ${ }^{1}$ Department of Family Resource Management, ${ }^{2}$ Department of Food and Nutrition, COHS, \\ CCSHAU, Hisar, India \\ *Corresponding author
}

\section{Keywords}

Depression, Elderly, Health, Personal profile, Social profile

Article Info

Accepted:

12 April 2019

Available Online:

10 May 2019

\section{A B S T R A C T}

Human ageing is associated with a wide range of physiological changes that not only make us more susceptible to death, but also limit the normal functions and render us to be more susceptible to a number of diseases. A study was conducted on 60 elderly people of age ranging from 60-80 years in Hisar district of Haryana state living in different lifestyle i.e. living with family, living without family and living in old age homes. Majority of the respondents $(46.67 \%)$ were in the age group of 70-79 years followed by $38.33 \%$ between 60-69 years of age. 33.33 percent of the respondents were living each in nuclear and joint family system while the rest were living in others that included old age homes of Hisar city. Majority of the respondents were living in a family of up to 5 members only. $33.33 \%$ of the elderly lived alone. Majority of the elderly $(70 \%)$ were married while $1.67 \%$ of them were unmarried. 23.33 percent of the respondents were widower. $40 \%$ of respondents was uneducated followed by 30 percent having studied up to metric and $10+2$ and $21.67 \%$ who had passed graduate and post graduate. $66.67 \%$ of the respondent were physically dependent on heavy work. 23.33 percent elderly were having no physical dependency followed by $10 \%$ having partial dependency. Majority of respondent (57 out of 60 respondents) had various types of old aged related problems. Perusal of results of the current study revealed that out of the total study sample 35\% of the senior citizens had severe psychological depression.

\section{Introduction}

Ageing is progressive functional decline or a gradual deterioration of physiological function with age, including a decrease in fecundity or the intrinsic, inevitable and irreversible age-related process of loss of viability and increase in vulnerability. Depression itself refers to a heterogeneous set of phenomenon ranging from simple mood swings to severe affective state. A meta- analysis reported the worldwide prevalence rate of depressive disorders in elderly population between 4.7 to $16 \%$ with comparatively higher prevalence of $21.9 \%$ in India. Geriatric depression is a major health hazard with devastating outcomes. Depression in old age is quite complex and it is much difficulty in diagnosis due to medical illnesses, dementia syndromes and heterogeneity of patients in the population. Depression is one of the leading causes of 
disability, representing significant costs to individuals, families and society.

The direct cost of managing chronic depression is estimated at twice the cost of managing hypertension and diabetes combined. Given the increased burden of depression anticipated by the WHO, the situation looms as a particular challenge to the health care system. Diagnosis of depression in seniors varies according to care setting, with the lowest levels reported among people living in the community ( $1 \%$ to $5 \%$ ) and the highest levels among those in long-term care facilities (14\% to $42 \%$ ). The purpose of this study was to assess the physical health and their direct and indirect effect of depression on old adults.

The main objectives of study were to evaluate the physical health of elderly and measure the depression among elderly.

\section{Review of literature}

Study by Brar et al., (2013) expressed that there was no significant correlation between Depression, Loss of Behavioral and Emotional control and Life satisfaction (variables of Mental Health) with variables of Wellbeing. Anxiety (variable of Mental Health) showed negative significant correlation with Wellbeing composite, Sociability, Emotional stability (variable of Wellbeing) and Wellbeing at 0.01 level of significance and with Self-esteem/Self confidence (Mental Health variable) at 0.05 level of significance.

Finding by Yadav and Agarwal (2014) appraised that age of elderly have positive and significant correlation with loneliness and spiritual well-being. Further loneliness was higher among resident of old age home against the one residing at home. The widow respondents felt more loneliness than married, divorced and widower.
Sharma and Mahavidyalya (2014) exposed that institutionalized older people were more depressed as compare to non-institutionalized older people. The difference in mean and SD showed that institutionalized people had poorer psychological well-being and life style. After intervention significant difference $(p<0.01)$ was found on leisure time activities, psychological well-being and life style.

Study by Sharma et al., (2015) explained that retirement specific self-esteem, dispositional rigidity, goal-directedness, social support (reliable alliance and reassurance of worth), regretfulness, leisure time activities, and family structure were the significant predictors of psychological well-being of retirees.

The selected variables put together explained 93\% of variance in the psychological wellbeing of retirees. The analysis revealed that the retirees with low and high psychological wellbeing found to differ on attitude towards aging, retirement specific self-esteem, dispositional rigidity, goal directedness, perceived social support, household decision making, regretfulness and leisure time activities. The study had implications for identifying and training retirees for better psychological well-being.

Mughal and Fatma (2015) advocated that the elderly females were more depressed $(\mathrm{M}=32.7)$ than male $(\mathrm{M}=19.33)$. Further regarding psychological well-being the elderly males received higher mean (150.93) as compared to females (131.26) and the tvalue was 2.88 , significant at 0.01 levels.

While correlation between depression and psychological wellbeing among elderly males and females reveals that there is positive correlation among elderly males and a negative correlation among elderly females. 
Materials and Methods

\section{Locale of the study}

Hisar city of Haryana state was selected purposively as locale of the present study.

\section{Selection of area}

The different locality of Hisar city and one old age home were selected randomly.

\section{Selections of sample}

From different locality of Hisar city, 10 male and 10 female respondents were selected each from those living without families, living with families and living in old age home of Hisar city thus, making a sample size of total 60 respondents. The age of the respondents varied from 60 years to 80 years.

\section{Selection of the respondents}

The data was collected from the elderly living with families, living without families and the elderly living in old age homes. A total sample of 60 comprising of 20 each from each section will be selected.

\section{Variable and their measurement}

Two types of variables were selected for the study i.e. independent and dependent.

\section{Independent variable}

Schedule were prepared for independent variables

a) Personal variable: Age, Gender and Living arrangement.

b) Social variables: Family type, size of family, marital status and Education. c) Level of physical dependency

d) Common health problem

\section{Dependent variable}

For, Depression Status, Geriatric Depression Scale (1986) was used for it.

\section{Tools of data collection}

An interview schedule was prepared for measuring independent variable and for measuring dependent variable Geriatric Depression Scale (1986) was used. Data were collected personally by researcher. The respondents were informed about the purpose of the study clearly. A questionnaire was used for collecting general information and for specific information.

\section{Analysis and interpretation of data}

After collecting data, the codes were assigned for detailed analysis. Based on the finding of the study and conclusions drawn on the basis of statistical analysis results were interpreted and recorded.

\section{Results and Discussion}

The data were collected in accordance with the research methodology to achieve the specific objectives of the study. Results based on the statistical analysis of the data are presented in the following subsection as given below:

Personal profile of respondents

Social profile of respondents

Health related aspects

Depression Status among elderly

Personal profile of respondents

Personal profile of respondents 
The personal profile of the respondents under the present study considered information with regard to some important personal variables viz. age and living arrangements of respondents.

The results have been presented in Table 1. It was observed that out of the total sample, majority of the respondents $(46.67 \%)$ were in the age group of 70-79 years followed by $38.33 \%$ between $60-69$ years of age. Regarding living arrangements, results depicted that among the elderly of 60-69 years of age $20 \%$ of respondents (12 out of 60 ) were living without family, followed by $16.67 \%$ and $10 \%$ who were living with family and in old age home respectively.

Among the elderly of 70-79 years of age, $15 \%$ were living in old age homes followed by $13.33 \%$ and $10 \%$ who were living with family and without family, respectively. 8.33 percent of elderly of 80 years and above were living old age homes while $3.33 \%$ were living each with family and without family, respectively.

\section{Social profile of respondents}

The data pertaining to social profile of the respondents are given in Table 2.

The main variables considered under the social profile of the respondents included family type, family size, marital status and education. Data from the current study revealed that 33.33 percent of the respondents were living each in nuclear and joint family system while the rest were living in others that included old age homes of Hisar city. $46.67 \%$ (28/60) of the respondents were living in a family of up to 5 members only and only $20 \%$ were living in family of more than 5 members. $33.33 \%$ of the elderly lived alone. Majority of the elderly (70\%) were married while $1.67 \%$ of them were unmarried. 23.33 percent of the respondents were widower and only $5 \%$ were divorcee. Further probing of data envisaged that highest percentage i.e. $40 \%$ of respondents was uneducated followed by 30 percent having studied up to metric and $10+2$ and $21.67 \%$ who had passed graduate and post graduate.

\section{Health related aspects}

Data portrayed in Table 3 highlights the results related to frequency distribution of respondents on various aspects of health.

It was observed that majority i.e. $66.67 \%$ of the respondent were physically dependent on heavy work. 23.33 percent elderly were having no physical dependency means they were independent followed by $10 \%$ having partial dependency. Results pertaining to suffering from different diseases showed that majority of respondent (57 out of 60 respondents) had various types of old aged related problems and only 5\% of them were free from any diseases.

As far as data pertaining to the severity of the diseases is considered, it was seen that $65 \%$ of the diseases were mild in nature followed by $30 \%$ that were severe health problems and 5\% as normal category. Further 68.33\% respondents reported that they had no medical insurance but $31.67 \%$ had health insurance. Further probing of data confirmed that $63.3 \%$ senior citizen used to undergo regular health checkup.

\section{Depression status}

The data pertaining to depression status of respondents have been incorporated in Table 4.

Perusal of results of the current study revealed that out of the total study sample $35 \%$ of the senior citizens had severe psychological depression, ranging severity from 20-30 on a 
scale of 0-30. Reason behind this finding may be that that majority of the respondents were above 70 years of age. 33.33 percent and
31.67 percent of the respondents were facing a state of normal and mild depression, respectively.

Table.1 Personal profile of respondents

$(\mathrm{n}=60)$

\begin{tabular}{|l|c|c|c|c|c|c|c|c|}
\hline Variables & \multicolumn{2}{|c|}{$\begin{array}{c}\text { Living with } \\
\text { family }\end{array}$} & \multicolumn{2}{c|}{$\begin{array}{c}\text { Living without } \\
\text { family }\end{array}$} & \multicolumn{2}{c|}{$\begin{array}{c}\text { Living in old } \\
\text { age home }\end{array}$} & \multicolumn{2}{|c|}{ Total } \\
\hline & $\begin{array}{c}\text { Men } \\
(\mathbf{1 0})\end{array}$ & $\begin{array}{c}\text { Women } \\
(\mathbf{1 0})\end{array}$ & $\begin{array}{c}\text { Men } \\
\mathbf{( 1 0 )}\end{array}$ & $\begin{array}{c}\text { Women } \\
(\mathbf{1 0})\end{array}$ & $\begin{array}{c}\text { Men } \\
(\mathbf{1 0})\end{array}$ & $\begin{array}{c}\text { Women } \\
(\mathbf{1 0})\end{array}$ & $\begin{array}{c}\text { Men } \\
\mathbf{( 3 0 )}\end{array}$ & $\begin{array}{c}\text { Women } \\
(\mathbf{3 0})\end{array}$ \\
\hline Age (in years) & \multicolumn{2}{|c|}{} & \multicolumn{2}{|c|}{} & & & & \\
\hline $60-69$ & 5 & 5 & 6 & 6 & 2 & 4 & 13 & 15 \\
\hline $70-79$ & 4 & 4 & 3 & 3 & 5 & 4 & 12 & 11 \\
\hline 80 and above & 1 & 1 & 1 & 1 & 3 & 2 & 5 & 4 \\
\hline
\end{tabular}

Table.2 Social profile of respondents

$(\mathrm{n}=60)$

\begin{tabular}{|c|c|c|c|c|c|c|c|c|}
\hline \multirow[t]{2}{*}{ Variables } & \multicolumn{2}{|c|}{$\begin{array}{l}\text { Living with } \\
\text { family }\end{array}$} & \multicolumn{2}{|c|}{$\begin{array}{l}\text { Living without } \\
\text { family }\end{array}$} & \multicolumn{2}{|c|}{$\begin{array}{l}\text { Living in old } \\
\text { age home }\end{array}$} & \multicolumn{2}{|c|}{ Total } \\
\hline & $\begin{array}{c}\text { Men } \\
\text { (10) }\end{array}$ & $\begin{array}{l}\text { Women } \\
\text { (10) }\end{array}$ & $\begin{array}{c}\text { Men } \\
\text { (10) }\end{array}$ & $\begin{array}{c}\text { Women } \\
\text { (10) }\end{array}$ & $\begin{array}{c}\text { Men } \\
\text { (10) }\end{array}$ & $\begin{array}{c}\text { Women } \\
\text { (10) }\end{array}$ & $\begin{array}{c}\text { Men } \\
\text { (30) }\end{array}$ & $\begin{array}{c}\text { Women } \\
\text { (30) }\end{array}$ \\
\hline \multicolumn{9}{|l|}{ Family type } \\
\hline Nuclear & 0 & 0 & 10 & 10 & 0 & 0 & 10 & 10 \\
\hline Extended & 0 & 0 & 0 & 0 & 0 & 0 & 0 & 0 \\
\hline Joint & 10 & 10 & 0 & 0 & 0 & 0 & 10 & 10 \\
\hline Others & 0 & 0 & 0 & 0 & 10 & 10 & 10 & 10 \\
\hline \multicolumn{9}{|l|}{ Family size } \\
\hline Up to 5 members & 4 & 4 & 10 & 10 & 0 & 0 & 14 & 14 \\
\hline Above 5members & 6 & 6 & 0 & 0 & 0 & 0 & 6 & 6 \\
\hline Living alone & 0 & 0 & 0 & 0 & 10 & 10 & 10 & 10 \\
\hline \multicolumn{9}{|l|}{ Marital status } \\
\hline Widowed / Widower & 0 & 0 & 0 & 0 & 6 & 8 & 6 & 8 \\
\hline Divorced & 0 & 0 & 0 & 0 & 2 & 1 & 2 & 1 \\
\hline Married & 10 & 10 & 10 & 10 & 1 & 1 & 21 & 21 \\
\hline Unmarried & 0 & 0 & 0 & 0 & 1 & 0 & 1 & 0 \\
\hline \multicolumn{9}{|l|}{ Education } \\
\hline Illiterate & 6 & 8 & 3 & 5 & 0 & 2 & 9 & 15 \\
\hline Primary & 1 & 1 & 0 & 0 & 1 & 2 & 2 & 3 \\
\hline Matric and $10+2$ & 2 & 1 & 3 & 2 & 6 & 4 & 11 & 7 \\
\hline $\begin{array}{l}\text { Graduate/ Post } \\
\text { graduate }\end{array}$ & 1 & 0 & 4 & 3 & 3 & 2 & 8 & 5 \\
\hline
\end{tabular}




\begin{tabular}{|c|c|c|c|c|c|c|c|c|}
\hline \multirow[t]{2}{*}{ Variables } & \multicolumn{2}{|c|}{$\begin{array}{l}\text { Living with } \\
\text { family }\end{array}$} & \multicolumn{2}{|c|}{$\begin{array}{l}\text { Living } \\
\text { without } \\
\text { family }\end{array}$} & \multicolumn{2}{|c|}{$\begin{array}{l}\text { Living in old } \\
\text { age home }\end{array}$} & \multicolumn{2}{|c|}{ Total } \\
\hline & $\begin{array}{l}\text { Men } \\
(10)\end{array}$ & $\begin{array}{l}\text { Women } \\
(10)\end{array}$ & $\begin{array}{c}\text { Men } \\
(10)\end{array}$ & $\begin{array}{l}\text { Women } \\
(10)\end{array}$ & $\begin{array}{c}\text { Men } \\
(10)\end{array}$ & $\begin{array}{c}\text { Women } \\
(\mathbf{1 0})\end{array}$ & $\begin{array}{c}\text { Men } \\
\text { (30) }\end{array}$ & $\begin{array}{c}\text { Women } \\
(\mathbf{3 0})\end{array}$ \\
\hline \multicolumn{9}{|c|}{ Level of physical dependency } \\
\hline Independency & 1 & 1 & 5 & 4 & 2 & 1 & 8 & 6 \\
\hline $\begin{array}{l}\text { Dependent on heavy } \\
\text { work }\end{array}$ & 8 & 9 & 4 & 5 & 6 & 8 & 18 & 22 \\
\hline Partially & 1 & 0 & 1 & 1 & 2 & 1 & 4 & 2 \\
\hline \multicolumn{9}{|l|}{ Suffering any diseases } \\
\hline Yes & 8 & 9 & 10 & 10 & 10 & 10 & 28 & 29 \\
\hline No & 2 & 1 & 0 & 0 & 0 & 0 & 2 & 1 \\
\hline \multicolumn{9}{|l|}{ Health problem } \\
\hline Normal & 2 & 1 & 0 & 0 & 0 & 0 & 2 & 1 \\
\hline Mild & 7 & 7 & 8 & 7 & 6 & 4 & 21 & 18 \\
\hline Severe & 1 & 2 & 2 & 3 & 4 & 6 & 7 & 11 \\
\hline \multicolumn{9}{|l|}{ Health insurance } \\
\hline Yes & 6 & 5 & 4 & 4 & 0 & 0 & 10 & 9 \\
\hline No & 4 & 5 & 6 & 6 & 10 & 10 & 20 & 21 \\
\hline \multicolumn{9}{|l|}{ Regular check up } \\
\hline Yes & 2 & 1 & 2 & 2 & 0 & 0 & 4 & 3 \\
\hline No & 0 & 0 & 0 & 0 & 10 & 10 & 10 & 10 \\
\hline
\end{tabular}

Table.4 Depression status of respondents

$$
\mathrm{n}=60
$$

\begin{tabular}{|l|c|c|c|c|c|c|c|c|}
\hline \multirow{2}{*}{ Variables } & \multicolumn{2}{|c|}{$\begin{array}{c}\text { Living with } \\
\text { family }\end{array}$} & \multicolumn{2}{c|}{$\begin{array}{c}\text { Living without } \\
\text { family }\end{array}$} & \multicolumn{2}{c|}{$\begin{array}{c}\text { Living in old } \\
\text { age home }\end{array}$} & \multicolumn{2}{c|}{ Total } \\
\cline { 2 - 9 } & $\begin{array}{c}\text { Men } \\
(\mathbf{1 0})\end{array}$ & $\begin{array}{c}\text { Women } \\
(\mathbf{1 0})\end{array}$ & $\begin{array}{c}\text { Men } \\
(\mathbf{1 0})\end{array}$ & $\begin{array}{c}\text { Women } \\
(\mathbf{1 0})\end{array}$ & $\begin{array}{c}\text { Men } \\
(\mathbf{1 0})\end{array}$ & $\begin{array}{c}\text { Women } \\
(\mathbf{1 0})\end{array}$ & $\begin{array}{c}\text { Men } \\
(\mathbf{3 0})\end{array}$ & $\begin{array}{c}\text { Women } \\
(\mathbf{3 0})\end{array}$ \\
\hline Normal (0-9) & 8 & 6 & 2 & 2 & 1 & 1 & 11 & 9 \\
\hline Mild (10-19) & 2 & 3 & 6 & 5 & 2 & 1 & 10 & 9 \\
\hline $\begin{array}{l}\text { Severe (20- } \\
\text { 30) }\end{array}$ & 0 & 1 & 2 & 3 & 7 & 8 & 9 & 12 \\
\hline
\end{tabular}




\section{Correlation between variables}

\begin{tabular}{|l|l|l|l|l|l|}
\hline Variables & Age & $\begin{array}{l}\text { Family } \\
\text { type }\end{array}$ & $\begin{array}{l}\text { Marital } \\
\text { status }\end{array}$ & $\begin{array}{l}\text { Size of } \\
\text { family }\end{array}$ & $\begin{array}{l}\text { Health } \\
\text { proble } \\
\text { m }\end{array}$ \\
\hline Correlation & 0.35 & 0.38 & -0.26 & 0.29 & 0.61 \\
\hline
\end{tabular}

In conclusion

Majority of the senior citizens in this study were in the age group of 70-79 years.

With increasing age group, more proportion of the elderly was reported to live in old age home as compared to those living with or without family.

Percentage of elderly living in nuclear, joint or old age homes were found to be invariably the same with majority of them reported to be married and uneducated.

Majority of respondents needed physical dependency but had no health insurance.

Only $1 / 3^{\text {rd }}$ of the elderly were psychologically well being.

\section{References}

Bishop, D. S., Epstein, N. B. and Keitner, G. I. (1986). Stroke: morale, family functioning, health status, and functional capacity. Archives of Physical Medicine and Rehabilitation, 67(2): 84-87.

Brar, R., Kaur, K., and Sharma, I. (2013). Mental health of elderly as related to their well being and self esteem. International Journal of Humanities and Social Science Invention. 2:54-57.

G. I. J. M. Kempen, J. Ormel, E. I. Brilman, and J. Relyveld (1997). "Adaptive responses among Dutch elderly: the impact of eight chronic medical conditions on healthrelated quality of life," American Journal of
Public Health, vol. 87, no. 1, pp. 38-44.

Kaplan, G. and O. Baron-Epel (2003). "What lies behind the subjective evaluation of health status?" Social Science and Medicine, vol. 56, no. 8, pp. 1669-1676.

Smith, J. (2001). "Well-being and health from age 70 to 100: findings from the Berlin aging study," European Review, vol. 9, no. 4, pp. 461-477, 2001.

Mughal, M.W. and Fatma, N. (2015). Psychological well-being and depression among inhabitants of old age homes of Jaipur, Rajasthan. Indian Journal of Applied Research, 5(6): 271-273.

Revicki, D. A. and Mitchell, J. P.(1990). Strain, social support, and mental health in rural elderly individuals. Journals of Gerontology, 45(6): S267-S274.

Sharma, N. K., Karunanidhi, S. and Chitra, T. (2015). Determinants of Psychological Well-being among Retirees. International Research Journal of Social Sciences, 4: 1926.

Sharma, R. and Mahavidyalya, A. (2014). Psychological well-being of institutionalized and non-institutionalized Senior Citizens. Gerontology \& Geriatric Research, 3:1-6.

Yadav, S. and Agarwal, S. (2014). Loneliness and spiritual well - being among elderly having psychological disorders. International Journal of Science and Research, 3: 22892290.

\section{How to cite this article:}

Rupal Hooda, Tanvi Bansal and Kiran Singh. 2019. Assessment of Depression Status of Older Adults of Hisar City. Int.J.Curr.Microbiol.App.Sci. 8(05): 1506-1512. doi: https://doi.org/10.20546/ijcmas.2019.805.173 